\title{
Integrating camera traps and community knowledge to assess the status of the Indian pangolin Manis crassicaudata in the Eastern Ghats, India
}

\author{
Vikram Aditya, Krishna Pavan Komanduri \\ Rohit Subhedar and Thyagarajan Ganesh
}

\begin{abstract}
Pangolins are the most trafficked animals globally. Although the Indian pangolin Manis crassicaudata occurs across the Indian subcontinent (excluding parts of the Himalayas and the north-east, where the Chinese pangolin Manis pentadactyla is present), it is categorized as Endangered on the IUCN Red List as a result of heavy poaching for its meat and scales. Several areas have not yet been surveyed for the occurrence of the Indian pangolin, one of which is the $16,948 \mathrm{~km}^{2}$ tropical deciduous forests of the northern Eastern Ghats landscape in Andhra Pradesh. During December 2017-April 2018, we surveyed $750 \mathrm{~km}^{2}$ of this landscape for the presence of the Indian pangolin, using camera traps. As an alternative method to document pangolin presence, and to identify factors driving hunting of the species, we also conducted, during the same period, a total of 60 semi-structured interviews with people in 30 villages. Interviewees reported the presence of pangolins in a majority of the grid cells that we surveyed with camera traps, particularly in moist deciduous forests distant from villages. However, the camera traps did not detect pangolins in 840 trap-days. Hunting of pangolins for their meat, which is consumed locally, and for their scales, which are traded, is most likely the reason for the rarity of the species in this landscape. A better understanding of the proximate and ultimate drivers of pangolin hunting is required, to inform proactive conservation management for this increasingly threatened species.
\end{abstract}

Keywords Andhra Pradesh, community observations, Eastern Ghats, hunting, India, Indian pangolin, Manis crassicaudata, wildlife trade

\footnotetext{
Vikram Aditya (Corresponding author, (D) orcid.org/0000-0003-3888-4369) and Thyagarajan Ganesh (D orcid.org/0000-0002-1327-0347) Ashoka Trust for Research in Ecology and the Environment, Royal Enclave, Sriramapura, Jakkur post, Bangalore 560064, India. E-mail vikram.aditya@atree.org

KrISHNA PaVAn Komanduri (D orcid.org/0000-0002-1849-9474) Bharati Vidyapeeth Deemed University, Institute of Environment Education and Research, Pune, India

Rohit SubHedaR* (DD orcid.org/0000-0002-5594-7600) Wildlife Conservation Society-India, Bengaluru, Karnataka, India

${ }^{*}$ Also at: Bharati Vidyapeeth Deemed University, Institute of Environment Education and Research, Pune, India

Received 10 January 2019. Revision requested 5 March 2019.

Accepted 28 October 2019. First published online 13 October 2020.
}

Supplementary material for this article is available at https://doi.org/10.1017/So030605319001303

\section{Introduction}

T unting and the associated trade in wildlife have been 1 widely acknowledged as a major driver of biodiversity loss and as a threat to mammals worldwide, particularly in tropical countries (Kumara \& Singh, 2004; Velho et al., 2012; Benítez-López et al., 2017). Hunting and illegal wildlife trade have severely affected all eight species of pangolins, particularly the four Asian species. Pangolins are believed to be the most trafficked animals globally (Wu et al., 2004; Baillie et al., 2014; Zhou et al., 2014; Challender, 2015; Challender et al., 2015). The seizure of illegally trafficked pangolins and their body parts continues unabated, with $>1$ million pangolins trafficked globally during 2000-2013 (Challender et al., 2014).

The Indian pangolin Manis crassicaudata, categorized as Endangered on the IUCN Red List (Baillie et al., 2014), is one of two pangolin species occurring in India (the other is the Critically Endangered Chinese pangolin Manis pentadactyla). The Indian pangolin is included under Schedule 1 Part 1 of the Indian Wild Life (Protection) Act, 1972, which legally protects the species and prohibits its hunting in India, and is on Appendix I of CITES, which prohibits all commercial international trade (CITES, 2017) and places it under a zero export quota (Challender et al., 2015; Hua et al., 2015; Mohapatra et al., 2015). Pangolins feed almost exclusively on ants and termites, thus playing an important role in the tropical forest ecosystem (Mohapatra \& Panda, 2014).

Although previously widely distributed across the Indian subcontinent, the Indian pangolin population has significantly declined throughout its range, largely as a result of widespread hunting and trade driven by the demand for the species' skin, scales and meat, both locally and elsewhere, and particularly in East Asia ( $\mathrm{Wu} \& \mathrm{Ma}$, 2007; Mahmood et al., 2012; Mishra \& Panda, 2012; Challender, 2015; Challender et al., 2015; Nijman et al., 2016). Destruction of its habitat across India has also contributed to the species' decline (Mishra \& Panda, 2012; Trageser et al., 2017). The CITES wildlife trade database shows that pangolin parts are also traded for traditional medicine and for making leather products (Mohapatra et al., 2015; UNEPWCMC, 2020). Nevertheless, there have been few studies of 
the species' status, distribution and habitat preferences across the Indian subcontinent (but see Srinivasulu et al., 2004; Mahmood et al., 2012, 2014; Trageser et al., 2017). This paucity of information potentially hinders the conservation of the species.

The Indian pangolin occurs across a range of habitat types, from natural forests to timber plantations, and over o-2,000 m altitude (Perera et al., 2017; Karawita et al., 2018). The species is secretive, cryptic and nocturnal (Karawita et al., 2018). Previous studies have shown that standard ecological monitoring techniques are not effective for surveying pangolins and that there is a need for secondary sources of information on presence (Newton et al., 2008; Nash et al., 2016; Karawita et al., 2018). Determining presence using a combination of field surveys and local community knowledge is critical to prioritize habitats for the species' conservation (Yoccoz et al., 2001; Newton et al., 2008; O'Brien, 2008).

The northern Eastern Ghats landscape of Andhra Pradesh and Odisha in southern India has vast stretches of contiguous forests (Aditya \& Ganesh, 2019). Although there have been few biodiversity studies in this landscape and only $3.53 \%$ of the total area is protected (Cardillo et al., 2006; Aditya \& Ganesh, 2019), it supports several rare, endemic and threatened species including the Jeypore ground gecko Cyrtodactylus jeyporensis (Agarwal et al., 2012), yellow-throated bulbul Pycnonotus xantholaemus (Sreekar \& Srinivasulu, 2010), forest owlet Heteroglaux blewetti (Kumar et al., 2010), leopard cat Prionailurus bengalensis, rusty-spotted cat Prionailurus rubiginosus, and stripenecked mongoose Herpestes vitticollis (Aditya \& Ganesh, 2016, 2017), highlighting the conservation significance of this landscape. Although pangolins are known to be hunted in this landscape (Mohapatra et al., 2015; Aditya, 2019), systematic information on their occurrence in this region is lacking (Srinivasulu et al., 2004). To address this, we used a combination of camera traps and local reports to assess the occurrence of the Indian pangolin in the northern Eastern Ghats. We also highlight the main patterns and drivers of hunting in this region.

\section{Study area}

The $16,948 \mathrm{~km}^{2}$ northern Eastern Ghats of Andhra Pradesh, India, are a series of discontinuous hills oriented in a northsouth direction; they include one protected area, the $1,012 \mathrm{~km}^{2}$ Papikonda National Park. There are several Reserve Forests, and a mosaic of other non-forest land uses surrounding the Park, including plantations and farmland (Fig. 1). The topography is mountainous, with altitudes of $20-1,680 \mathrm{~m}$. Mean annual precipitation is $1,309 \mathrm{~mm}$ (Goswami et al., 2018). The dominant forest type is southern tropical mixed moist deciduous, with some semi-evergreen patches (Champion \&
Seth, 1968). The flora is dominated by large trees such as Anogeissus latifolia, Terminalia tomentosa, Terminalia arjuna and Tectona grandis.

The northern Eastern Ghats is an important forested corridor between the Western Ghats and north-east Indian biodiversity hotspots (Goswami et al., 2018). Various Indigenous communities inhabit the landscape, mainly the plains dwelling Koyas, who are cultivators, and the hill dwelling Konda Reddis, who subsist on non-timber forest produce and shifting cultivation. Other communities include the Parajas, Bagathas and Valmikis, all of whom depend on the forests for their livelihoods. The study area consists of various Reserve Forests around Papikonda National Park in East Godavari and Visakhapatnam districts, encompassing dry deciduous, moist deciduous and semi-evergreen forests, plantations, some agricultural fields and 30 villages (Fig. 1).

\section{Methods}

Camera-trap surveys We procured LANDSAT 8 satellite imagery from Google Earth Engine (Gorelick et al., 2017). The image was used to generate a classified habitat map based on pre-existing maps (Buckland et al., 2001) and ground-based training points, through supervised classification (Jha et al., 2000; Vaidyanathan et al., 2010), using the classification and regression tree classifier in Google Earth Engine. We divided the study area into $512,5 \times 5 \mathrm{~km}$ grid cells and used stratified random sampling to select 30 cells (a total of $750 \mathrm{~km}^{2}$ ) from dry and moist deciduous forest patches. We also identified villages within the 30 selected grid cells for conducting interviews. The cells are at altitudes of 200-1,000 m. We used a total of 16 motion-activated Trinetra (REAP, Bangalore, India), Bushnell Aggressor (Bushnell, Kansas City, USA) and ScoutGuard Attack (ScoutGuard, Molendinar, Australia) digital camera traps with a passive infrared sensor, with the sensitivity set to high, at a height of c. $0.5 \mathrm{~m}$ above ground, during December 2017-April 2018. Camera traps were placed within each cell based on local information regarding areas with a high likelihood of pangolin occurrence, such as pangolin burrows, hill slopes, streams and near salt licks. Camera traps were set for a minimum of 7 days at each location and then moved to another cell. Indirect signs of pangolins, such as scrape marks on termite mounds, were noted but were not considered a definitive indication of presence. The total survey effort was 840 trap-days $(20,160$ traphours).

Interviews We identified and mapped all villages in the study area using topographical sheets from the Survey of India, and obtained data on the village populations, tribal groups (as identified by the Census of India, 2001) and 


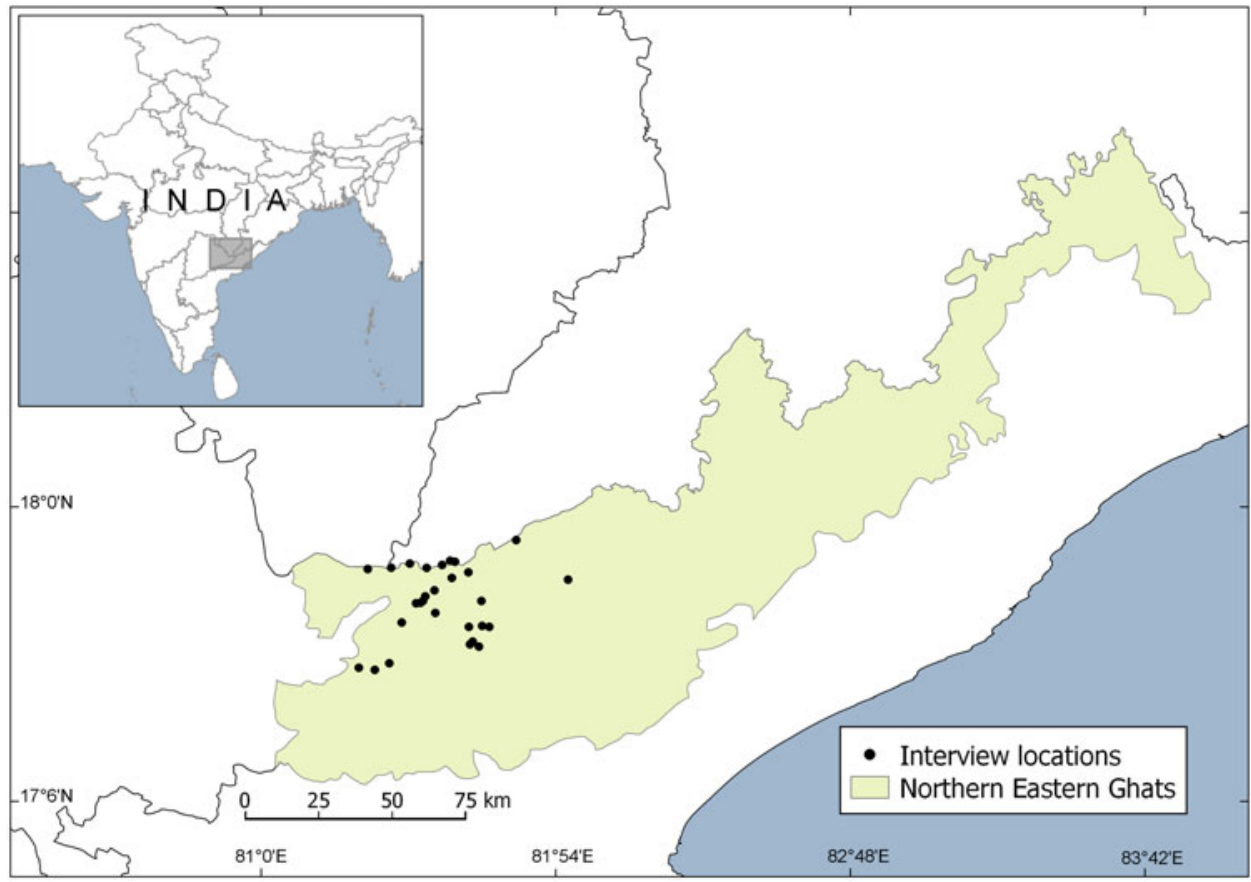

FIG. 1 The northern Eastern Ghats landscape in Andhra Pradesh, India, indicating the villages in which we conducted interviews for assessing the presence of the Indian pangolin Manis crassicaudata.

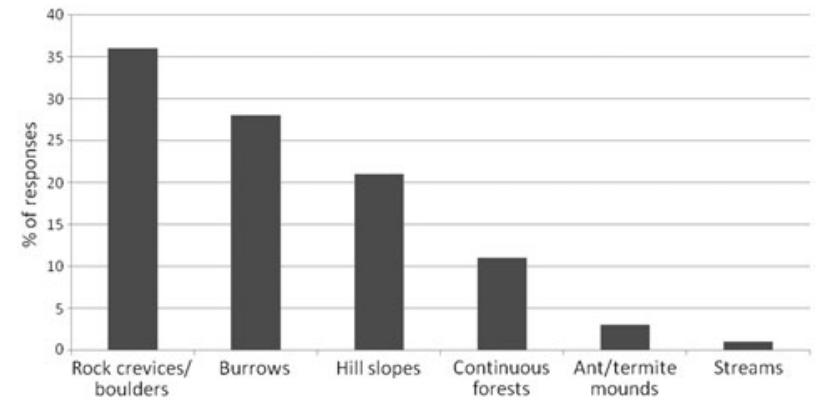

FIG. 2 Per cent of the 60 interviewees who mentioned each of the six locations where pangolins were observed.

per cent of the population in each village that is tribal (Census of India, 2001). We conducted a total of 60 interviews in 30 villages, using a semi-structured questionnaire (Supplementary Material 1), during August 2017-April 2018. We used a convenience sampling approach to assess drivers of hunting qualitatively rather than to facilitate generalization of any findings to a wider population (Newing, 2010). Interviews were conducted by four people (VA, KP, RS and a member from the local Koya community) in either Telugu or Koya, as required. Older male respondents, usually aged above 50, who were active hunters, were selected for interviews. Interview questions focused on three broad themes: (1) pangolin occurrence in the landscape, (2) pangolin habitat preferences and (3) hunting practices and trade in pangolins. Interviewees were first shown photographs of the pangolin and asked if they could identify it. We used open-ended questions to obtain qualitative data. Verbal consent was obtained from respondents before the interview. We used a smartphone to record interviews. After transcription of the interviews we used thematic coding to identify themes emerging from our data, which we report using per cent response frequencies. The occurrence of pangolins was estimated from where they were reported, as sightings, localities of capture, or from the presence of pangolin body parts such as scales.

\section{Results}

Occurrence recorded by camera traps The camera traps photographed 18 species of mammals, including the gaur Bos gaurus, sloth bear Melursus ursinus, four-horned antelope Tetracerus quadricornis and sambar Rusa unicolor, all of which are categorized as Vulnerable on the IUCN Red List (IUCN, 2019). However, none of the camera traps captured pangolins.

Occurrence reported by interviewees The majority of the respondents $(88 \%)$ correctly identified the pangolin when shown photographs of the animal. More than half of the respondents (53\%) reported seeing the animal, $30 \%$ had never seen it, and the rest were unsure if they had seen it. Nearly all respondents (93\%) felt that pangolin numbers had declined drastically over the previous 10 years. Respondents mentioned six habitat types in which they had seen a pangolin (Fig. 2), with most having been seen amongst rock crevices/boulders, next to their burrows or on slopes; $3 \%$ of respondents reported having seen pangolins feed on ants and termites. 
Hunting and trade Interviewees reported that several techniques were employed to hunt pangolins (Fig. 3), with the most common being to locate a burrow and dig the pangolin out, and to hunt with bow and arrow. Most interviewees reported that they primarily targeted the Indian muntjac Muntiacus muntjak and wild pig Sus scrofa rather than pangolins. Hunting in general peaked during the Bhumi panduga festival, a tribal festival celebrated at the onset of the monsoon season (June-July) across central and southern India during which villagers hunt in groups of 30-100 individuals; $80 \%$ of the interviewees said they still celebrated Bhumi panduga. A range of reasons were given for hunting pangolins (Fig. 4); obtaining scales for trade and meat for consumption were the most common. A small per cent reported using scales for medicinal purposes (for the cure of piles and kidney stones). There was a strong belief that scales shaped into rings (Plate 1) are a defence against black magic; $83 \%$ of the respondents said pangolin scales were the primary animal part traded. None of the interviewees reported trading of meat either locally or otherwise; it was considered a delicacy, eaten after boiling the animal to remove the scales. Rates received for $1 \mathrm{~kg}$ of pangolin scales were INR 10,000-20,000 (USD 138-277), depending on the size and condition of the scales. Most scales were traded locally through middlemen and to nearby towns and cities such as Rajahmundry. Although the trade for export abroad from middlemen and exporters was reportedly well organized, interviewees were apparently not familiar with the trade routes.

\section{Discussion}

We believe this is the first baseline assessment of pangolin occurrence, hunting and trade in the northern Eastern Ghats landscape. Our findings indicate that hunting of pangolins in the region is driven by both commercial (scales for trade) and personal (meat, scales for making rings) reasons. In 20,160 trap-hours we did not, however, detect any pangolins in our 16 camera traps. Camera-trap surveys conducted by us and covering $232 \mathrm{~km}^{2}$ inside Papikonda National Park and its buffer in 2014-2015, with a survey effort of 19,512 trap-hours, also failed to detect pangolins (Aditya \& Ganesh, 2019), highlighting the potential difficulty of using camera traps to survey rare and elusive species. Ninety-three per cent of the respondents reported a decline in pangolin numbers over the previous decade. This apparent reduction in the population along with the species' secretive nature could have affected our ability to detect it with camera-trap surveys. An alternative explanation is that the Indian pangolin could now be locally extirpated in the northern Eastern Ghats. Ingram et al. (2018) recommended that for fossorial species such as pangolins several techniques, such as identification of active burrows for the

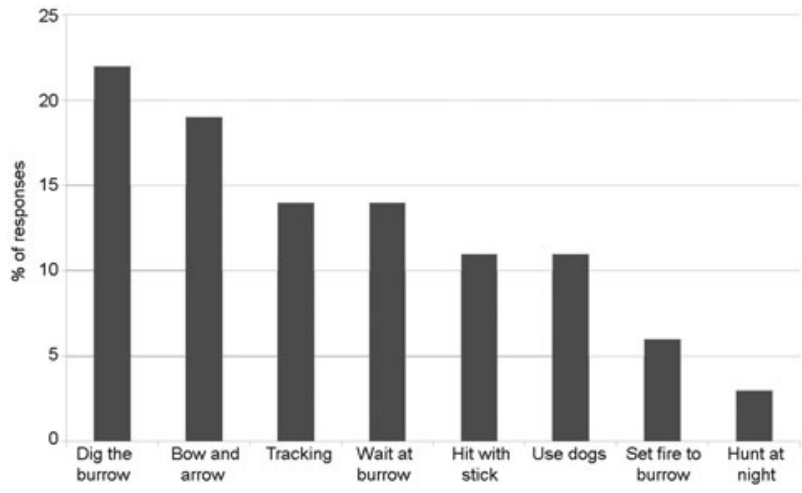

FIG. 3 Per cent of the 60 interviewees who mentioned each of the eight methods employed for hunting pangolins.

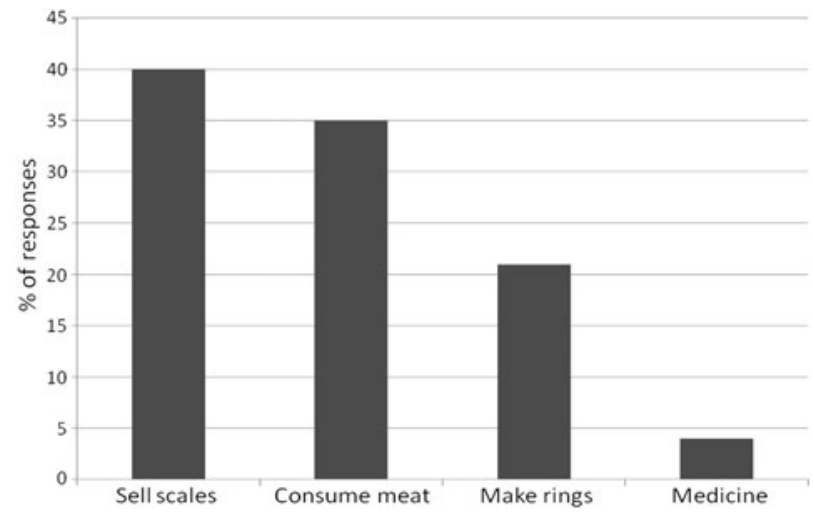

FIG. 4 Per cent of the 60 interviewees who mentioned each of the five reasons given for hunting pangolins.

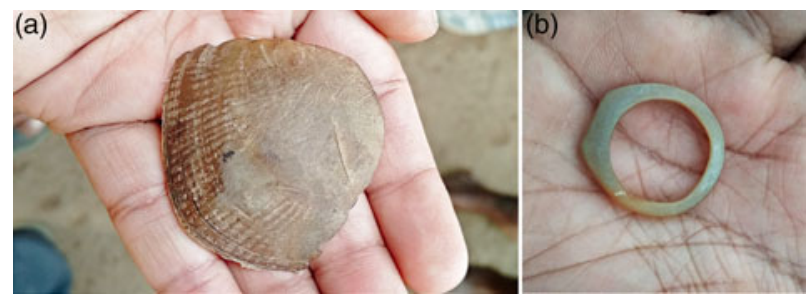

Plate 1 (a) Sale of a hunted pangolin, and (b) ring made out of a pangolin scale.

setting of camera traps, combined with data from hunters and markets, might be effective in monitoring populations.

Investigating occurrence and habitat preferences is important for designing effective conservation interventions for pangolins, particularly in landscapes such as the northern Eastern Ghats, where mammals face a high risk of extinction (Cardillo et al., 2004, 2006; Aditya \& Ganesh, 2019). Interviewees indicated that pangolins prefer burrowing in areas with rock crevices and/or boulders, and on hill slopes, consistent with the findings of Karawita et al. (2018), suggesting that people in the local communities have informal 
knowledge about pangolin ecology that could be incorporated into conservation planning of the species.

Hunting is a significant threat to wildlife globally (Harrison et al., 2016). It negatively affects mammal populations even in protected landscapes such as the Western Ghats and the Indian Himalayas (Kumara \& Singh, 2004; Velho et al., 2012; Benítez-López et al., 2017). One interviewee noted:

'They were never in abundance; we look for their burrows and dig them out. I have made several attempts to find it so that I can earn some money. The last one we hunted was about a decade ago since then we have not seen one.'

Hunting has significantly reduced the populations of mammals, birds and reptiles in the northern Eastern Ghats (Ganesh et al., 2015). During the interviews, people reported hunting using a variety of strategies, including setting fires in the dry season to clear the undergrowth to ensure better visibility for hunting.

Interviewees suggested that the pangolin population has decreased and cited hunting as the prime reason. Our findings suggest that pangolin hunting was mostly opportunistic, occurring when an active burrow is encountered, as in Assam (D'Cruze et al., 2018). Hunting techniques, such as digging out burrows and tracking with dogs, as described by respondents, are similar to those described in other studies (Newton et al., 2008). Our findings with respect to the use of rings carved from pangolin scales, which is rooted in superstitious beliefs and perceived medicinal properties, are consistent with the findings of Mohapatra et al. (2015).

The selling price of pangolin scales that we recorded (INR 10,000-20,000; USD 138-277 per kg), was markedly lower than prices reported in neighbouring Nepal (USD 500-625 per $\mathrm{kg}$ ) and Bangladesh (USD 500 per $\mathrm{kg}$ ) (Katuwal et al., 2015; Trageser et al., 2017). This is consistent with observations from other studies (Nooren \& Claridge, 2001; Newton et al., 2008). Prices for pangolin scales in India have nevertheless risen. For instance, in the state of Mizoram, $1 \mathrm{~kg}$ of scales fetched INR 1,000 in 1996, INR 13,000 in 2013 and INR 17,000 in 2017, in line with inflation in India over this period (D'Cruze et al., 2018).

We recommend that, to ensure the long-term persistence of the Indian pangolin in the northern Eastern Ghats, further research is carried out to identify both the proximate and ultimate drivers of pangolin hunting. We recommend that local authorities shift from a reactive (e.g. seizures of scales) to a proactive enforcement strategy (prevention of pangolin hunting) by engaging with local communities to understand their socio-economic needs and socio-cultural practices, and to understand market conditions that result in the hunting of pangolins (Dixit et al., 2010; Mohapatra et al., 2015). Targeted awareness programmes in the local languages could be initiated to communicate the urgency of the situation, and the dangers of consumption of wild meat, in the form of emerging zoonotic infections, could be specifically emphasized. The chain of pangolin trade needs to be halted by taking steps to prevent hunting and supply to local middlemen. Setting up rescue, rehabilitation and breeding centres for pangolins rescued from illegal trade (Hua et al., 2015) could contribute to the future recovery of the population in the Eastern Ghats.

Acknowledgements We thank the Wildlife Conservation Trust, India, for financial and equipment support for this project, and the Conservation Leadership Programme, The Rufford Foundation, Idea Wild and ReAP for the continuing support, particularly for equipment. We thank the Andhra Pradesh Forest Department for granting us the necessary permits and for field assistance, Arvind Thurram for field assistance, Ovee Thorat for her input, and the Editor and two reviewers for their helpful comments.

Author contributions Study design: all authors; field work: VA, KP, RS; data analysis, writing: all authors.

\section{Conflicts of interest None.}

Ethical standards This study was conducted with permission from the Andhra Pradesh Forest Department. Respondents' names were recorded only if they wished us to do so (to recontact them if necessary), and names and locations were held confidentially. The research abided by the Oryx guidelines on ethical standards.

\section{References}

Aditya, V. (2019) How the cyber revolution is fuelling wildlife poaching in India: the story of the pangolin. Current Conservation, currentconservation.org/issues/how-the-cyber-revolution-isfueling-wildlife-poaching-in-india-the-story-of-the-pangolin [accessed July 2020].

Aditya, V. \& GAnesh, T. (2016) Camera trap records of rusty-spotted cat Prionailurus rubiginosus and leopard cat Prionailurus bengalensis (Mammalia: Carnivora: Felidae) from Papikonda National Park, northern Eastern Ghats, India. Journal of Threatened Taxa, 8, 8818-8819.

Aditya, V. \& Ganesh, T. (2017) Mammals of Papikonda Hills, northern Eastern Ghats, India. Journal of Threatened Taxa, 9, 10823-1083O.

Aditya, V. \& Ganesh, T. (2019) Deciphering forest change: linking satellite-based forest cover change and community perceptions in a threatened landscape in India. Ambio, 48, 790-80o.

Agarwal, I., Dutta-Roy, A., Bauer, A.M. \& Giri, V.B. (2012) Rediscovery of Geckoella jeyporensis (Squamata: Gekkonidae), with notes on morphology, coloration and habitat. Hamadryad, 36, 17-24.

Baillie, J., Challender, D., Kaspal, P., Khatiwada, A., Mohapatra, R. \& Nash, H. (2014) Manis crassicaudata. In The IUCN Red List of Threatened Species 2014: e.T12761A45221874. dx.doi.org/10.2305/IUCN.UK.2014-2.RLTS.T12761A45221874.en [accessed 13 March 2020].

Benítez-López, A., Alkemade, R., Schipper, A.M., Ingram, D.J., Verweij, P.A., Eikelboom, J.A.J. \& Huijbregts, M.A.J. (2017) The impact of hunting on tropical mammal and bird populations. Science, 356, 180-183.

Buckland, S.T., Anderson, D., Burnham, K., Laake, J., Thomas, L. \& Borchers, D. (2001) Introduction to Distance Sampling: Estimating Abundance of Biological Populations. Oxford University Press, Oxford, UK. 
Cardillo, M., Purvis, A., Sechrest, W., Gittleman, J.L., Bielby, J. \& MACE, G.M. (2004) Human population density and extinction risk in the world's carnivores. PLOS Biology, 2, e197.

Cardillo, M., Mace, G.M., Gittleman, J.L. \& Purvis, A. (2006) Latent extinction risk and the future battlegrounds of mammal conservation. Proceedings of the National Academy of Sciences of the United States of America, 103, 4157-4161.

Census of India (2001) Andhra Pradesh Data Highlights: The Scheduled Tribes. Census of India 2001, Office of the Registrar General, India. censusindia.gov.in/Tables_Published/SCST/dh_st_ andhra.pdf [accessed 18 March 2020].

Challender, D.W., Waterman, C. \& Baillie, J.E.M. (2014) Scaling up Pangolin Conservation. IUCN Species Survival Commission Pangolin Specialist Group Conservation, Zoological Society of London, UK.

Challender, D.W. (2015) The Most Traded Wild Mammal-the Pangolin-is Being Eaten to Extinction. IUCN, Gland, Switzerland.

Challender, D.W., Harrop, S.R. \& MacMillan, D.C. (2015) Understanding markets to conserve trade-threatened species in CITES. Biological Conservation, 187, 249-259.

Champion, S.H. \& Seth, S.K. (1968) A revised survey of the forest types of India. In A Revised Survey of the Forest Types of India. Manager of Publications, Delhi, India.

CITES (2017) Final Decisions Made at CoP17 on the Proposals to Amend CITES Appendices. cites.org/sites/default/files/eng/cop/ 17/Decisions-on-amendment-proposals.pdf [accessed 18 May 2020].

D'Cruze, N., Singh, B., Mookerjee, A., Harrington, L.A. \& Macdonald, D.W. (2018) A socio-economic survey of pangolin hunting in Assam, Northeast India. Nature Conservation, 30, 83-105.

Dixit, A.K., Kadavul, K., Rajalakshmi, S. \& Shekhawat, M.S. (2010) Ethno-medico-biological studies of South India. Indian Journal of Traditional Knowledge, 9, 116-118.

Ganesh, T., Aditya, V., Malla, G. \& Prashanth, M.B. (2015) The 'empty forests' of the northern Eastern Ghats. Current Science, 109, 398-399.

Gorelick, N., Hancher, M., Dixon, M., Ilyushchenko, S., Thau, D. \& Moore, R. (2017). Google Earth Engine: planetary-scale geospatial analysis for everyone. Remote Sensing of Environment, 202, 18-27.

Goswami, R., Thorat, O., Aditya, V. \& Karimbumkara, S.N. (2018) A preliminary checklist of butterflies from the northern Eastern Ghats with notes on new and significant species records including three new reports for peninsular India. Journal of Threatened Taxa, 10, 12769-12791.

Harrison, R.D., Sreekar, R., Brodie, J.F., Brook, S., Luskin, M., O'KeLLY, H. et al. (2016) Impacts of hunting on tropical forests in Southeast Asia. Conservation Biology, 30, 972-981.

Hua, L., Gong, S., WANG, F., Li, W., Ge, Y., Li, X. \& Hou, F. (2015) Captive breeding of pangolins: current status, problems and future prospects. ZooKeys, 507, 99-114.

Ingram, D.J., Coad, L., Abernethy, K.A., Maisels, F., Stokes, E.J., Вово, K.S. et al. (2018) Assessing Africa-wide pangolin exploitation by scaling local data. Conservation Letters, 11, e12389.

IUCN (2019) The IUCN Red List of Threatened Species 2019-3. iucnredlist.org [accessed 17 March 2020].

Jha, C.S., DutT, C.B.S. \& Bawa, K.S. (200o) Deforestation and land use changes in Western Ghats, India. Current Science, 79, 231-238.

Karawita, H., Perera, P., Gunawardane, P. \& Dayawansa, N. (2018) Habitat preference and den characterization of Indian Pangolin (Manis crassicaudata) in a tropical lowland forested landscape of southwest Sri Lanka. PLOS ONE, 13, e0206082.
Katumal, H.B., Neupane, K.R., Adhikari, D., Sharma, M. \& ThapA, S. (2015) Pangolins in eastern Nepal: trade and ethno-medicinal importance. Journal of Threatened Taxa, 7, 7563-7567.

Kumar, T.S., Chandra, R. \& Azeez, P.A. (2010) The birds of Araku, Visakhapatnam, Andhra Pradesh, India. Journal of Threatened Taxa, 2, 662-665.

Kumara, H.N. \& Singh, M. (2004) The influence of differing hunting practices on the relative abundance of mammals in two rainforest areas of the Western Ghats, India. Oryx, 38, 321-327.

Mahmood, T., Hussain, R., Irshad, N., Akrim, F. \& Nadeem, M.S. (2012) Illegal mass killing of Indian pangolin (Manis crassicaudata) in Potohar region, Pakistan. Pakistan Journal of Zoology, 44, 1457-1461.

Mahmood, T., Irshad, N. \& Hussain, R. (2014) Habitat preference and population estimates of Indian pangolin (Manis crassicaudata) in District Chakwal of Potohar Plateau, Pakistan. Russian Journal of Ecology, 45, 70-75.

Mishra, S. \& PANDA, S. (2012) Distribution of Indian pangolin Manis crassicaudata Gray (Pholidota, Manidae) in Orissa: a rescue prospective. Small Mammal Mail, 3, 51-53.

Mohapatra, R.K. \& PANDA, S. (2014) Husbandry, behaviour and conservation breeding of Indian pangolin. Folia Zoologica, $63,73-81$

Mohapatra, R.K., Panda, S., Acharjyo, L., Nair, M. \& Challender, D.W. (2015) A note on the illegal trade and use of pangolin body parts in India. Traffic Bulletin, 27, 33-40.

NAsh, H.C., Wong, M.H. \& Turvey, S.T. (2016) Using local ecological knowledge to determine status and threats of the Critically Endangered Chinese pangolin (Manis pentadactyla) in Hainan, China. Biological Conservation, 196, 189-195.

Newing, H. (2010) Conducting Research in Conservation: Social Science Methods and Practice. Routledge, Milton Park, UK.

Newton, P., Van Thai, N., Roberton, S. \& Bell, D. (2008) Pangolins in peril: using local hunters' knowledge to conserve elusive species in Vietnam. Endangered Species Research, 6, 41-53.

Nijman, V., Zhang, M.X. \& Shepherd, C.R. (2016) Pangolin trade in the Mong La wildlife market and the role of Myanmar in the smuggling of pangolins into China. Global Ecology and Conservation, 5, 118-126.

Nooren, H. \& Claridge, G. (2001) Wildlife Trade in Laos: The End of the Game. IUCN, Gland, Switzerland.

O'BRIEN, T.G. (2008) On the use of automated cameras to estimate species richness for large- and medium-sized rainforest mammals. Animal Conservation, 11, 179-181.

O’Connell, A.F., Nichols, J.D. \& Karanth, K.U. (eds) (2010) Camera Traps in Animal Ecology: Methods and Analyses. Springer Science \& Business Media, Berlin/Heidelberg, Germany.

Perera, P.K.P., Karawita, K.V.D.H.R. \& Pabasara, M.G.T. (2017) Pangolins (Manis crassicaudata) in Sri Lanka: a review of current knowledge, threats and research priorities. Journal of Tropical Forestry and Environment, 7, 1-14.

SReekar, R. \& SRinivasulu, C. (2010) New site record of yellow-throated bulbul Pycnonotus xantholaemus from Andhra Pradesh. Journal of the Bombay Natural History Society, 92, 266-267.

Srinivasulu, C., Srinivasulu, B., Rajesh, A., Rao, C.A.N. \& NAGULU, V. (2004) Non-volant small mammals of Kasu Brahmananda Reddy National Park, Andhra Pradesh. Zoos' Print Journal, 19, 1495-1497.

Trageser, S.J., Ghose, A., Faisal, M., Mro, P., Mro, P. \& Rahman, S.C. (2017) Pangolin distribution and conservation status in Bangladesh. PLOS ONE, 12, eo175450.

UNEP-WCMC (2020) CITES Trade Database. trade.cites.org [accessed 18 March 2020]. 
Vaidyanathan, S., Krishnaswamy, J., Kumar, N.S., Dhanwatey, H., Dhanwatey, P. \& Karanth, K.U. (2010) Patterns of tropical forest dynamics and human impacts: views from above and below the canopy. Biological Conservation, 143, 2881-2890.

Velho, N., Karanth, K.K. \& Laurance, W.F. (2012) Hunting: A serious and understudied threat in India, a globally significant conservation region. Biological Conservation, 148, 210-215.

$\mathrm{W}_{\mathrm{U}}, \mathrm{S} . \mathrm{B}$. \& $\mathrm{MA}$, G.Z. (2007) The status and conservation of pangolins in China. TRAFFIC East Asia Newsletter, 4, 1-5.
Wu, S., Liu, N., Zhang, Y. \& MA, G.Z. (2004) Assessment of threatened status of Chinese Pangolin (Manis pentadactyla). Chinese Journal of Applied and Environmental Biology, 10, 456-461. Yoccoz, N.G., Nichols, J.D. \& Boulinier, T. (2001) Monitoring of biological diversity in space and time. Trends in Ecology \& Evolution, 16, 446-453.

Zhou, Z.M., Zhou, Y., Newman, C. \& Macdonald, D.W. (2014) Scaling up pangolin protection in China. Frontiers in Ecology and the Environment, 12, 97-98. 